\title{
Does a family history of prostate cancer affect screening behavior in Jamaican men?
}

\author{
Belinda F. Morrison ${ }^{1}$ and Yulit Gordon ${ }^{2}$
}

Suggested citation Morrison BF, Gordon Y. Does a family history of prostate cancer affect screening behavior in Jamaican men? Rev Panam Salud Publica. 2018;42:e143. https://doi.org/10.26633/RPSP.2018.143

\begin{abstract}
Objective. To determine 1) the characteristics of males with a family history of prostate cancer who presented for screening and 2) the association between family history and diagnosis of prostate cancer in a cohort of screened Jamaican men.

Methods. The study consisted of a prospective cohort of black men who screened at the Jamaica Cancer Society in Kingston between 2006 and 2016. Data were collected on: 1) age at screening and age at diagnosis of prostate cancer, 2) family history of prostate cancer, and 3) prostate-specific antigen (PSA) and digital rectal examination (DRE) findings.

Results. Approximately $600(21.4 \%)$ of screened men who reported data on family history (2 791 / 2 867) said they had a family history of prostate cancer. Men with a family history of prostate cancer 1) commenced screening at a younger age than men without a family history $(\mathrm{P}<0.001)$ and 2$)$ tended to have a younger age at diagnosis of prostate cancer $(\mathrm{P}=0.262)$. There was no significantly increased risk of prostate cancer in men with a reported family history of prostate cancer (odds ratio: $1.4 ; 95 \%$ confidence interval: $0.821-2.386 ; \mathrm{P}=0.217$ ).

Conclusions. Men with a family history of prostate cancer presented frequently for screening and earlier than those without. There was a lack of association between family history of prostate cancer and diagnosis. Further studies are needed to investigate this association and validate family histories.
\end{abstract}

Keywords Prostate cancer; mass screening; risk factors; Jamaica; Caribbean region.

Prostate cancer is commonly seen in men in the Americas, disproportionately affecting black men. Incidence rates for prostate cancer in Jamaica are high, with the disease representing approximately $21 \%$ of all cancers seen in males in the country (1). Prostate cancer mortality rates in Jamaica are also high, and the rates for the Caribbean region overall are the highest in the world $(2,3)$. Several

\footnotetext{
Department of Surgery, University of the West Indies-Mona, Kingston, Jamaica. Send correspondence to: Belinda F Morrison, bfmorrison11@ hotmail.com

2 Jamaica Cancer Society, Kingston, Jamaica.
}

clinico-pathological reports on prostate cancer in Jamaica have documented advanced stages at presentation $(4,5)$. Evidence suggests that screening reduces prostate cancer mortality (6). However, several barriers to early detection exist in Jamaica, including cultural barriers, fear of the diagnosis, and concerns regarding treatment-related morbidity (7). Therefore, screening for prostate cancer is not a widespread practice in Jamaica.

A family history of prostate cancer is a significant risk factor for development of the disease (8-10). Few studies have investigated this association in a predominantly black population. Glover et al. reported a twofold increase in the risk of development of prostate cancer in Jamaican men with a first-degree relative with the disease (11). This risk increased to threefold in men with a second-degree relative (11). Similar increased risks were demonstrated in a largely Afro-Caribbean population in Barbadian men (12). A large case-control study in the United States showed no ethnic difference in the increased risk of prostate cancer in men with a significant family history (13). However, in a multiracial cohort study of patients diagnosed with prostate cancer, 
African-American men were more likely than Caucasians and Hispanics to have a family history of prostate cancer (14).

Case-by-case decision-making on prostate cancer screening is 1) recommended by the American Urological Association (AUA) for males 40-54 years old with a family history of the disease or African ethnicity and 2) suggested by the AUA for all men aged 55-69 years (15). Spain et al. reported that African-American men with a family history of prostate cancer failed to appreciate their increased risk for the disease, and this risk factor did not influence screening behaviors (16). Bloom et al. found that African-American men with a family history of prostate cancer did not consider themselves "high-risk" but were more likely to undergo prostate-specific antigen (PSA) screening than those without a family history of the disease (17).

This study aimed to determine 1) the characteristics of males with a family history of prostate cancer who presented for screening and 2) the association between family history and diagnosis of prostate cancer in a cohort of screened Jamaican men.

\section{MATERIALS AND METHODS}

\section{Study population}

The study consisted of a prospective cohort of males screened at the Jamaica Cancer Society (JCS) Prostate Cancer Screening Clinic, located in the city of Kingston, which comprises about 23\% of the Jamaican population. The JCS clinic provides the largest and only organized prostate cancer screening clinic in Jamaica. Screening is conducted by multiple volunteer urologists who are members of the local Jamaica Urological Society (JUS). In addition to Kingston residents, a wide cross-section of patients from rural and other urban areas in Jamaica visit the JCS clinic for prostate cancer screening. While the JUS recommends annual prostate cancer screening for men 40-75 years old, this study cohort included all patients screened one or more times at the JCS clinic, regardless of age, between 1 January 2006 and 4 August 2016. All screened patients had presented voluntarily.

\section{Study variables}

Patient history of prostate pathology (e.g., benign prostatic hyperplasia or prostatitis) was not included in the analysis because this information was not available. All patients had a PSA screening and digital rectal examination (DRE), and trans-rectal ultrasoundguided (TRUS) biopsy was recommended for patients with abnormal findings. A PSA threshold of $4 \mathrm{ng} / \mathrm{ml}$ was generally used as the criterion for recommending a biopsy, along with age-specific PSA ranges in African-American males described by Moul (18). Family history data on prostate cancer among parents, siblings, or other relatives were obtained but did not 1) influence the clinician's decision to recommend a biopsy, or the timing of the biopsy, or 2) alter the frequency of future screening recommended by the clinician (annually, for those with normal DRE / PSA findings; variable / at the discretion of the urologist for those with abnormal findings). Positive and negative family histories were not validated as no national cancer registry exists in Jamaica. Histopathology reports were also obtained for all patients who received TRUS biopsies. All diagnoses of prostate cancer were based on these reports.

\section{Ethical considerations}

Ethical approval was obtained from the Institutional Review Board of the University of the West Indies. All procedures performed in studies involving human participants were in accordance with the ethical standards of the institutional and/or national research committee and with the 1964 Helsinki declaration and its later amendments or comparable ethical standards.

\section{Statistical analysis}

Data were summarized as means and medians for count and numeric variables and categorical variables were summarized as percentages. Bivariate associations were tested using one-sample $t$-tests and chi-square tests of association. To answer the research questions, logistic regression models predicting an outcome of prostate cancer were estimated. Data were analyzed with Stata Statistical Software, version 12 for Windows (StataCorp LP, College Station, TX, USA).

\section{RESULTS}

A total of 2867 men were screened at the JCS clinic between 1 January 2006 and 4 August 2016 during 1-21 visits each (mean: 2; median: 1 ). The mean age of screening was 54.1 years (range: 37-100; median: 53). The median PSA finding for the group was $138 \mathrm{ng} / \mathrm{ml}$ (range: 1-885). Approximately $97 \%$ (2 786) of the 2867 patients had a clinically benign prostate during all their presentations for screening. Approximately $21.4 \%$ of patients (597 out of 2791 ) had a family history of prostate cancer, and $2.8 \%$ (81 out of 2867 ) were ultimately diagnosed with prostate cancer. Patient mean age at diagnosis was 61.9 years (range: 43-73; median: 63) (Table 1). Of the patients diagnosed with adenocarcinoma of the prostate, a biopsy Gleason score of $3+3(6), 3+4(7), 4+3(7), 8$, and 9 was detected in $29(36 \%), 27(33 \%), 20$ $(25 \%), 3(4 \%)$, and $2(2 \%)$ respectively.

\section{Bivariate associations}

Family history. Patients with a family history of prostate cancer had a similar number of screening visits as those without a family history of the disease but were slightly younger at their first screening (52.8 versus 54.4 years; $P<0.001)$ and at diagnosis (60.1 versus 62.1 years; $P<0.262$, a non-statistically significant difference). There was no difference in the biopsy Gleason score for men with a family history of prostate

\section{TABLE 1. Summary of characteristics of men presenting for prostate cancer screening} at the Jamaica Cancer Society, Kingston, Jamaica, 1 January 2006-4 August 2016

\begin{tabular}{lccc}
\hline Characteristic & Mean & Median & Min-max $^{\mathrm{a}}$ \\
\hline No. of screening visits $(n=2867)$ & 2.0 & 1 & $1-21$ \\
Age at first screening (years) $(n=2844)$ & 54.1 & 53 & $37-100$ \\
Age at diagnosis (years) $(n=81)$ & 61.9 & No. (\%) \\
Had family history of prostate cancer $(n=2$ 791) & \multicolumn{2}{c}{$597(21.4)$} \\
Had prostate cancer $(n=2867)$ & \multicolumn{2}{c}{$81(2.8)$} \\
\hline
\end{tabular}

Source: Prepared by the authors based on the study results.

a Minimum-maximum. 
cancer compared to men without a family history of the disease $(P=0.419)$. There was a slightly higher prevalence of prostate cancer $(3.2 \%)$ in men with a family history of prostate cancer compared to prevalence in those with no family history of the disease $(2.6 \%)$, but this difference was not statistically significant (Table 2). Details on the relationship and number of family members with prostate cancer were not consistently present in the dataset, so sub-analyses of prevalence in first- / second-degree relatives and the association with risk of prostate cancer were not performed.
Diagnosis of prostate cancer. Patients with a diagnosis of prostate cancer had a greater mean number of screening visits compared to those without that diagnosis (2.6 visits versus 2.0 visits; $P=0.02$ ). Men with a diagnosis of prostate cancer were on average about six years older at their first screening than men without that diagnosis (59.8 years versus 54.0 years; $P<0.001$ ). There was a slightly higher prevalence of a family history of prostate cancer $(25.0 \%)$ among men with a diagnosis of prostate cancer compared to those without that diagnosis $(21.3 \%)$.

TABLE 2. Bivariate associations with family history of prostate cancer in men presenting for prostate cancer screening at the Jamaica Cancer Society, Kingston, Jamaica, 1 January 2006-4 August 2016

\begin{tabular}{|c|c|c|c|c|c|c|c|}
\hline \multirow{2}{*}{ Variable } & \multicolumn{3}{|c|}{ Family history of prostate cancer } & \multicolumn{3}{|c|}{ No family history of prostate cancer } & \multirow{2}{*}{$P$} \\
\hline & $n$ & Mean & $\mathrm{Cl}^{\mathrm{a}}$ & $n$ & Mean & $\mathrm{Cl}$ & \\
\hline No. of screening visits & 597 & 2.1 & $(1.9-2.2)$ & 2194 & 2.0 & $(1.9-2.1)$ & $0.768^{b}$ \\
\hline Age at first screening (years) & 593 & 52.8 & $(52.1-53.4)$ & 2175 & 54.4 & $(54.0-54.8)$ & $<0.001^{b}$ \\
\hline Age at diagnosis (years) & 19 & 60.1 & $(56.9-63.3)$ & 57 & 62.1 & $(60.3-63.9)$ & $0.262^{b}$ \\
\hline Had prostate cancer & \multicolumn{2}{|c|}{ №. $\%$} & & \multicolumn{2}{|c|}{ No. \% } & & $0.437^{c}$ \\
\hline
\end{tabular}

Source: Prepared by the authors based on the study results.

a $95 \%$ confidence interval for the mean.

${ }^{\mathrm{b}}$ Independent sample $t$-test.

c Pearson chi-square test.

TABLE 3. Bivariate associations with diagnosis of prostate cancer in men presenting for prostate cancer screening at the Jamaica Cancer Society, Kingston, Jamaica, 1 January 2006-4 August 2016

\begin{tabular}{|c|c|c|c|c|c|c|c|}
\hline \multirow{2}{*}{ Variable } & \multicolumn{3}{|c|}{ Prostate cancer } & \multicolumn{3}{|c|}{ No prostate cancer } & \multirow{2}{*}{ D } \\
\hline & $n$ & Mean & $\mathrm{Cl}^{\mathrm{a}}$ & $n$ & Mean & $\mathrm{Cl}$ & \\
\hline No. of screening visits & 81 & 2.6 & $(2.0-3.2)$ & 2786 & 2.0 & $(1.9-2.1)$ & $0.02^{b}$ \\
\hline Age at first screening (years) & 81 & 59.8 & $(58.3-61.4)$ & 2763 & 54.0 & $(53.6-54.3)$ & $<0.001^{\mathrm{b}}$ \\
\hline Had family history of prostate cancer & & $\begin{array}{l}\% \\
25.0)\end{array}$ & & $2715(21.3)$ & $\begin{array}{l}\% \\
21.3)\end{array}$ & & $0.437^{c}$ \\
\hline
\end{tabular}

Source: Prepared by the authors based on the study results.

a $95 \%$ confidence interval for the mean.

${ }^{\mathrm{b}}$ Independent sample $t$-test.

c Pearson chi-square test.

TABLE 4. Estimated odds ratio (OR) for a positive prostate cancer diagnosis, based on a multivariate regression model, for two characteristics in men presenting for prostate cancer screening at the Jamaica Cancer Society, Kingston, Jamaica, 1 January 2006-4 August 2016

\begin{tabular}{lcr}
\hline Positive prostate cancer diagnosis & $\mathrm{OR}\left(\mathrm{Cl}^{\mathrm{a}}\right)$ & $P$ \\
\hline Delayed initial screening $^{\mathrm{b}}$ & $1.068(1.043-1.093)$ & $<0.001$ \\
Family history of prostate cancer & $1.400(0.821-2.386)$ & 0.217 \\
\hline
\end{tabular}

Source: Prepared by the authors based on the study results.

a $95 \%$ confidence interval.

'Patients' odds of a diagnosis of prostate cancer increased by $7 \%$ each year that the initial screening was delayed.

However, this difference was not statistically significant (Table 3).

\section{Multivariate associations}

Diagnosis of prostate cancer. A multivariable logistic regression model to predict prostate cancer was estimated. The model (Table 4) indicated that patients' odds of a diagnosis of prostate cancer increased by $7 \%$ each year that the initial screening was delayed (odds ratio (OR): 1.07; $P<0.001$ ), and by $40 \%$ for those with a family history of prostate cancer compared to those with no family history of the disease (OR: $1.4 P=0.217$, a non -statistically significant increase).

\section{DISCUSSION}

Family history of prostate cancer is an established nonmodifiable risk factor for prostate cancer. Familial clustering of prostate cancer is well described in the literature, and several cases of hereditary and familial prostate cancer have been reported (19). Previous studies have shown that this risk increases with greater numbers of family members affected and with first-degree relatives with the disease versus second-degree relatives $(8,9)$. In this study, a relatively high proportion of men screened for prostate cancer reported a family history of the disease $(21.4 \%)$ (although these reports could not be validated as there is no national pathology database or cancer registry). According to the study results, while the group reporting a family history did tend to receive their first screening at a younger age, they did not have a significantly increased risk of developing the disease compared to those with no family history (there was a higher prevalence of family history of prostate cancer in men diagnosed with prostate cancer, but the finding was not statistically significant). However, the authors of this study consider the proportion reporting a family history of prostate cancer $(21.4 \%$ of the men screened at the JCS clinic in Kingston who reported data for that variable (2 791 out of 2 867)) to be high. In evaluating the impact of family history in the Finnish prostate cancer screening trial, Mäkinen et al. found that only $5 \%$ of men screened reported a family history of prostate cancer (20). A similar prevalence of family history of prostate cancer $(6.8 \%)$ was found in the Swiss arm of the European Randomised 
Study of Screening for Prostate Cancer (ERSPC) (21). Of 150000 persons screened in the Prostate, Lung, Colorectal, and Ovarian (PLCO) Cancer Screening Trial of the U.S. National Cancer Institute, $7.3 \%$ reported a family history of prostate cancer (22). In addition, though other studies may suggest that black men with a family history of prostate cancer do not engage in regular screening activities $(16,23,24)$, the authors of this study believe that having a family history of the disease did influence screening practices in the cohort, possibly due to selection bias resulting from JCS' numerous educational campaigns via print and electronic media informing men of risk factors for prostate cancer and screening guidelines. The authors believe that the earlier initial screening that occurred in those with a family history of the disease is also at least partly attributable to JCS public education campaigns targeting men at high risk for prostate cancer. The effect of these campaigns is shown by the fact that 2867 men were screened between 2006 and 2016 compared to 1117 men screened between 1995 and 2005 (7).

Though not statistically significant, in this study, men with a family history of prostate cancer also had a younger age at diagnosis of prostate cancer than those without. Similar findings were previously reported in a multiracial cohort of men that found that men with a family history of prostate cancer were diagnosed at 64.9 years compared to 66.9 years in men without a family history $(P<0.001)(14)$.

Family history of prostate cancer is useful for research on the role of genetics in prostate carcinogenesis, and the association of family history of prostate cancer with clinically significant prostate cancer is also of interest. Several genetic mutations are associated with increased prostate cancer risk, particularly at an early age of onset (25). In the Swiss arm of the ERSPC, the presence of a first-degree relative with prostate cancer increased the risk of low-grade but nonaggressive prostate cancer (21). Similar findings were reported in the Finnish prostate cancer screening trial, which found no difference in prostate cancer mortality based on reported family history (26). Some studies have reported that PSA testing inflates estimates of familial prostate cancer risk by detecting clinically insignificant cancers (27). In their study, Rudichuk et al. found that most urologists obtained men's family history of prostate cancer during screening and tended to opt for more aggressive treatment methods for those reporting relatives who had the disease (28). In the future, personalized medicine might allow for special screening advice and treatment in men with a family history of prostate cancer.

\section{Strengths and limitations}

The strengths of this study include its cohort design and the infrastructure of the data source-the JCS Prostate Cancer Screening Clinic, which provided data on multiple screening visits over several years. This study also had potential limitations. First, recall bias could have been an important issue, whereby persons may have been unable to recall medical histories of older family members (e.g., grandfathers). Second, in some cases where persons were from single parent families, full details on family history for fathers or other relatives would not have been possible. Third, non-validation of patients' report of a family history of prostate cancer could have resulted in misclassification, which could have created a form of information bias. This is particularly important in the Jamaican population, in which some persons assume all "prostate problems" are due to prostate cancer. Non-differential misclassification of exposure could have resulted in a dilution of the OR as reported.
Fourth, although there were no significant differences in the number of screening visits in men with family history of prostate cancer versus those without that characteristic, the overall results of prostate cancer in the screened group could have been affected by overdiagnosis bias. Finally, earlier diagnosis of prostate cancer in men with a family history could also have been due to an earlier age of presentation for screening, which could have resulted in a lead time bias manifesting with earlier age of diagnosis with the disease.

Despite these potential limitations, the study results show some of the positive results of the JCS clinic's efforts to increase the numbers of men screened and target those who are high-risk and have a family history of prostate cancer. The authors therefore recommend increased public health education and awareness campaigns targeting high-risk populations, and efforts to increase screening for prostate cancer. Further population studies assessing the association between a family history of prostate cancer and diagnosis need to be conducted and validated using cancer registries.

\section{Conclusions}

Men with a family history of prostate cancer presented for screening earlier than those without. There was no significant increased risk of prostate cancer in men with a family history of prostate cancer. Further studies are needed to investigate this association and validate family histories.

\section{Conflicts of interest. None.}

Disclaimer. Authors hold sole responsibility for the views expressed in the manuscript, which may not necessarily reflect the opinion or policy of the RPSP / PAJPH or the Pan American Health Organization (PAHO).

\section{REFERENCES}

1. Gibson TN, Hanchard B, Waugh N, McNaughton D. Age-specific incidence of cancer in Kingston and St. Andrew, Jamaica, 2003-2007. West Indian Med J. 2010;59(5):456-64.

2. Blake G, Hanchard B, Mitchell K, Simpson D, Waugh N, Wolff C, et al. Jamaica cancer mortality statistics, 1999. West Indian Med J. 2002;51(2):64-7.
3. Jemal A, Bray F, Center MM, Ferlay J, Ward E, Forman D. Global cancer statistics. CA Cancer J Clin. 2011;61(2): 69-90.

4. Coard KC, Skeete DH. A 6-year analysis of the clinicopathological profile of patients with prostate cancer at the University Hospital of the West Indies, Jamaica. BJU Int. 2009;103(11):1482-6.
5. Shirley SE, Escoffery CT, Sargeant LA, Tulloch T. Clinicopathological features of prostate cancer in Jamaican men. BJU Int. 2002;89(4):390-5.

6. Schröder FH, Hugosson J, Carlsson S, Tammela T, Määttänen L, Auvinen A, et al. Screening for prostate cancer decreases the risk of developing metastatic disease: findings from the European Randomized 
Study of Screening for Prostate Cancer (ERSPC). Eur Urol. 2012;62(5):745-52.

7. Morrison BF, Aiken W, Mayhew R, Gordon $Y$, Reid M. Prostate cancer screening in Jamaica: results of the largest national screening clinic. J Cancer Epidemiol. 2016; 2016:2606805.

8. Bruner DW, Moore D, Parlanti A, Dorgan J, Engstrom P. Relative risk of prostate cancer for men with affected relatives: systematic review and meta-analysis. Int J Cancer. 2003;107(5):797-803.

9. Johns LE, Houlston RS. A systematic review and meta-analysis of familial prostate cancer risk. BJU Int. 2003;91(9):789-94.

10. Kiciński M, Vangronsveld J, Nawrot TS. An epidemiological reappraisal of the familial aggregation of prostate cancer: a meta-analysis. PLoS One. 2011;6(10): e27130.

11. Glover FE Jr, Coffey DS, Douglas LL, Russell H, Cadigan M, Tulloch T, et al. Familial study of prostate cancer in Jamaica. Urology. 1998;52(3):441-3.

12. Nemesure B, Wu SY, Hennis A, Leske MC. Family history of prostate cancer in a black population. J Immigr Minor Health. 2013;15(6):1107-12.

13. Hayes RB, Liff JM, Pottern LM, Greenberg RS, Schoenberg JB, Schwartz AG, et al. Prostate cancer risk in U.S. blacks and whites with a family history of cancer. Int J Cancer. 1995;60(3):361-4.

14. Cotter MP, Gern RW, Ho GY, Chang RY, Burk RD. Role of family history and ethnicity on the mode and age of prostate cancer presentation. Prostate. 2002;50(4):216-21.
15. Carter HB, Albertsen PC, Barry MJ, Etzioni R, Freedland SJ, Greene KL, et al. Early detection of prostate cancer: AUA Guideline. J Urol. 2013;190(2):419-26.

16. Spain P, Carpenter WR, Talcott JA, Clark JA, Do YK, Hamilton RJ, et al. Perceived family history risk and symptomatic diagnosis of prostate cancer: the North Carolina Prostate Cancer Outcomes study. Cancer. 2008;113(8):2180-7.

17. Bloom JR, Stewart SL, Oakley Girvan I, Banks PJ, Chang S. Family history, perceived risk, and prostate cancer screening among African American men. Cancer Epidemiol Biomarkers Prev. 2006;15(11): 2167-73.

18. Moul JW. Screening for prostate cancer in African Americans. Curr Urol Rep. 2000;1(1):57-64.

19. Bratt O. Hereditary prostate cancer: clinical aspects. J Urol. 2002;168(3):906-13.

20. Mäkinen T, Tammela TL, Stenman UH, Määttänen L, Rannikko S, Aro J, et al. Family history and prostate cancer screening with prostate-specific antigen. J Clin Oncol. 2002;20(11):2658-63.

21. Randazzo M, Müller A, Carlsson S, Eberli D, Huber A, Grobholz R, et al. A positive family history as a risk factor for prostate cancer in a population-based study with organised prostate-specific antigen screening: results of the Swiss European Randomised Study of Screening for Prostate Cancer (ERSPC, Aarau). BJU Int. 2016;117(4):576-83.

22. Pinsky PF, Kramer BS, Reding D, Buys S; PLCO Project Team. Reported family history of cancer in the Prostate, Lung, Colorectal, and Ovarian Cancer Screening Trial. Am J Epidemiol. 2003;157(9):792-9.

23. Weinrich SP. Prostate cancer screening in high-risk men: African American Hereditary Prostate Cancer Study Network Cancer. 2006;106(4):796-803.

24. Drake BF, Lathan CS, Okechukwu CA, Bennett GG. Racial differences in prostate cancer screening by family history. Ann Epidemiol. 2008;18(7):579-83.

25. Giri VN, Beebe-Dimmer JL. Familial prostate cancer. Semin Oncol. 2016;43(5):560-5.

26. Saarimäki L, Tammela TL, Määttänen L, Taari K, Kujala PM, Raitanen J, et al. Family history in the Finnish Prostate Cancer Screening Trial. Int J Cancer. 2015;136(9):2172-7.

27. Bratt O, Drevin L, Akre O, Garmo H, Stattin P. Family History and Probability of Prostate Cancer, Differentiated by Risk Category: A Nationwide Population-Based Study. J Natl Cancer Inst. 2016;108(10): pii: djw110.

28. Rudichuk L, Vogel KJ, Wang CH, Helfand BT, Selkirk CG. Urologists' current practices in screening and treating men with a family history of prostate cancer. Urology. 2017;99:180-5. Epub 2016 Sep 16.

Manuscript submitted 17 November 2017. Revised version accepted for publication on 9 June 2018. 
RESUMEN

¿Influyen los antecedentes familiares de cáncer de próstata en la disposición de los hombres jamaiquinos a participar en pruebas de tamizaje?

Palabras clave
Objetivos. Determinar 1) las características de los hombres con antecedentes familiares de cáncer de próstata que se presentaron para el tamizaje, y 2) la asociación entre los antecedentes familiares y el diagnóstico de cáncer de próstata en la cohorte de hombres jamaiquinos que participó en el tamizaje.

Métodos. El estudio consistió en una cohorte prospectiva de hombres negros que se sometieron a un tamizaje realizado en la Jamaica Cancer Society [Sociedad del Cáncer de Jamaica] en Kingston entre el 2006 y el 2016. Se recopilaron los siguientes datos: 1) edad en el momento del tamizaje y edad en el momento del diagnóstico de cáncer de próstata, 2) antecedentes familiares de cáncer de próstata y 3) resultados del antígeno prostático específico (APE) y del tacto rectal (EDR).

Resultados. De los hombres que informaron antecedentes familiares en el tamizaje (2 791/2 867), aproximadamente 600 (21,4\%) tenían antecedentes familiares de cáncer de próstata. Los hombres con antecedentes familiares de cáncer de la próstata: 1) empezaron a participar en el tamizaje a una edad más temprana que los hombres sin antecedentes familiares $(P<0,001)$ y 2$)$ tenían una edad menor en el momento del diagnóstico de cáncer de próstata $(P=0,262)$. No se observó un aumento significativo en el riesgo de cáncer de próstata en hombres que informaron de antecedentes familiares de cáncer de próstata (razón de posibilidades [OD] de 1,4; intervalo de confianza de $95 \%$ : 0,821 - 2,386; $P=0,217)$.

Conclusiones. Los hombres con antecedentes familiares de cáncer de próstata se presentaron con frecuencia a las pruebas de tamizaje y a una edad más temprana que los hombres sin antecedentes. No se observó una asociación entre los antecedentes familiares de cáncer de próstata y el diagnóstico. Es necesario realizar estudios adicionales para investigar esta asociación y validar los antecedentes familiares.

Neoplasias de la próstata; tamizaje masivo; factores de riesgo; Jamaica; región del Caribe.

Objetivos. Determinar as características dos homens com história familiar de câncer de próstata que buscaram fazer o rastreamento e examinar a associação entre história familiar e diagnóstico de câncer de próstata em uma coorte de homens jamaicanos rastreados.

\section{Ter uma história familiar de câncer de próstata influi na conduta de rastreamento em homens jamaicanos?}

Palavras-chave
Métodos. O estudo compreendeu uma coorte prospectiva de homens negros que fizeram o rastreamento de câncer no serviço da Sociedade do Câncer da Jamaica em Kingston entre 2006 e 2016. Foram coletadas informações sobre: idade ao rastreamento e idade ao diagnóstico de câncer de próstata, história familiar de câncer de próstata e resultados da dosagem do antígeno prostático específico (PSA) e do exame de toque retal.

Resultados. Cerca de $600(\mathrm{n}=2.791 ; 21,4 \%$ ) dos homens rastreados que deram informações sobre a história familiar $(n=2.867)$ disseram que tinham história familiar de câncer de próstata. Os homens com história familiar de câncer de próstata: começaram o rastreamento quando eram mais jovens que os homens sem história familiar $(P<0,001)$ e tiveram uma tendência de serem mais jovens ao diagnóstico de câncer de próstata $(P=0,262)$. Não se observou risco significativamente maior de câncer de próstata nos homens com história familiar informada de câncer de próstata (odds ratio 1,4; intervalo de confiança de 95\% 0,821-2,386; $P=0,217$ ).

Conclusões. Os homens com história de câncer de próstata buscaram com frequência fazer o rastreamento e a uma idade mais jovem em relação aos homens sem história familiar. Observou-se a ausência de associação entre história familiar e diagnóstico de câncer de próstata. Outros estudos são necessários para investigar esta associação e validar as histórias familiares.

Neoplasias da próstata; programas de rastreamento; fatores de risco; Jamaica; região do Caribe. 